\title{
中枢神経系奇形児のカラードプラ断層法による脳血管像
}

\author{
田角 勝1), 久保田健夫 ${ }^{1)}$, 古荘純一1), \\ 奥山和男 ${ }^{1)}$, 土居 浩2), 川内章裕 ${ }^{3)}$ \\ 昭和大学医学部小児科1), 脳神経外科 ${ }^{2)}$, 外科 $^{3)}$
}

\section{Anomalies of Central Nervous System in Infancy ; Evaluation by Color Doppler Echoencephalography}

\author{
Masaru TATSUNO, M.D. ${ }^{1)}$, Takeo KUBOTA, M.D. ${ }^{1)}$, Junichi FURUSHO, M.D. ${ }^{1)}$, \\ Kazuo OKUYAMA M.D. ${ }^{1)}$, Hiroshi DOI M.D. ${ }^{2)}$, Akihiro KAWAUCHI M.D. ${ }^{3)}$
}

\author{
Department of Pediatrics ${ }^{1)}$, Neurosurgery ${ }^{2)}$ and Surgery ${ }^{3)}$, \\ Showa University School of Medicine, \\ (Received 18 September 1989, Accepted 14 December 1989)
}

\begin{abstract}
We performed 78 color Doppler examinations to demonstrate intracranial vasculature in 61 infants; 30 cases with normal and 19 with abnormal central nervous system anatomy. Developmental abnormalities such as hydrocephalus, hydranencephaly, holoprosencephaly, absent corpus callosum, and Dandy-Walker syndrome were demonstrated. Serial scans were obtained in sagittal, coronal, and axial plains. Most of the major intracranial arteries and veins could be clearly demonstrated in real-time. In patients with hydrocephalus, color Doppler imaging demonstrated a widely streched and elevated sweep of the anterior cerebral arteries, straightening of the middle cerebral arteries by the enlarged ventricles. The internal cerebral veins, great cerebral vein, straight sinus were straighted and displaced posteriorly and inferiorly. In infants with absent corpus callosum, anterior cerebral arteries and their branches appeared to be wavy. However, in patients with developmental abnormalities, visualizations of the vasculature were relatively poor. In conclusion, the color Doppler examination is a useful and practical method of imaging of cerebral vessels in infants, because of its noninvasiveness and portability.
\end{abstract}

Key words : Color Doppler imaging, Echoencephalography, Infant, Brain anomalies.

\section{1.はじめに}

超音波断層法は, 新生児·未熟児の脳出血, 頭蓋内奇形 などの中枢神経病変の診断において不可欠のものとなっ ている ${ }^{1)-3)}$. さらにドプラ法が応用され, 脳血流速の測定 が盛んに行わなれている(1)4)5. カラードプラ断層法は, 心 疾患に応用されて以来 ${ }^{6)-10)}$ 他臓器にもその利用が拡げら れ，装置の進歩により新生児頭部領域への応用もされつ
つある11)-15).

今回われわれは,カラードプラ断層法により新生児·乳 児期の中枢神経系奇形における脳血管像について検討し たので報告する.

\section{2. 対象および方法}

対象は, 1988年8月より1989年8月に昭和大学小児科に 入院した中枢神経系奇形を持つ新生児·乳児19例 $(0 \sim 303$

田角 勝：干142 東京都品川区旗の台 1-5-8 昭和大学医学部小児科

Masaru TATSUNO : Department of Pediatrics, Showa University School of Medicine,1-5-8 Hatanodai, Shinagawa-ku, Tokyo142. 
Table 1

\begin{tabular}{lc}
\hline Diagnosis & No. \\
\hline Normal & 30 \\
\hline Abnormal & 31 \\
Hydrocephalus & 10 \\
Hydranencephaly & 1 \\
Dandy-Walker syndrome & 2 \\
Holoprosencephaly & 2 \\
Absent corpus callosum & 1 \\
Arachnoid cyst + & 1 \\
Absent corpus callosum & \\
Cavum velum interpositum & 2 \\
Others & 12 \\
\hline
\end{tabular}

日齢 平均 73.2 日, 出生時体重: $2,220 \sim 3,675 \mathrm{~g}$ ) 平均 $2,895 \mathrm{~g}$, 検査時体重: $3,060 \sim 8,245 \mathrm{~g}$ 平均 $4,738 \mathrm{~g}$ とした. 検査は超音波センターまたはベッドサイドで延べ43回行 なわれた.そして，これら所見を正常新生児・未熟児30 例 (年齢：2１63日齢 平均46.2日，出生時体重：746 $3,824 \mathrm{~g}$ 平均 $2,852 \mathrm{~g}$, 検査時体重 : 642 5,204g 平均 2,503 g)における延べ35回の検査と比較して検討した.

中枢神経系異常は, 水頭症, hydranencephaly, DandyWalker症候群, Holoprosencephaly, 脳梁欠損症などであ つた (Table 1).

装置はSSA-270A 超音波診断装置（探触子：3. 75MHz(PSF-37CT)および5MHz(PSF-50AT), エレクト リックセクタ, 東芝社製)を用いた。 主に大泉門をエコー ウィンドウとして正中矢状断, 傍矢状断, 冠状断, そし て経側頭骨より水平断で検査を施行した。症例により小 泉門もエコーウィンドウとして用いた。記録は，ビデオ テープおよびインスタントフィルムで行なった. なお， CTはCTW600(日立社製)またはTCT60A27(東芝社製)， MRIはMRT-50A(0.5Tesla，東芝社製)を用いた。

\section{3. 結 果}

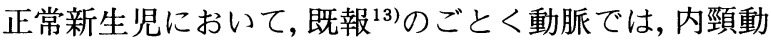
脈, 前大脳動脈, 傍脳梁動脈, 中大脳動脈, 後大脳動脈, 脳底動脈およびその分枝の描出が可能であった。静脈で は, 上·下矢状静脈洞, 内大脳静脈, 大大脳静脈, 直静脈 洞などの血管が描出できた．新生児における検査では， 大泉門を利用した正中矢状断で多くの血管像が得られ， さらに冠状断や傍矢状断そして水平断も有用と考えられ た. 正常児において各々の血管の最も良く描出できるエ コーウィンドウからの検出率は, Table 2のとおりであ った.
Table 2 Detection rate of intracranial vessels in normal infants.

\begin{tabular}{lr}
\hline Vessels & No. (\%) \\
\hline Arteries & \\
Anterior cerebral artery & $30 / 30(100)$ \\
Basilar artery & $30 / 30(100)$ \\
Callosomarginal artery & $23 / 30(77)$ \\
Frontopolar artery & $25 / 30(83)$ \\
Internal carotid artery & $30 / 30(100)$ \\
Lateral striate artery & $24 / 30(80)$ \\
Medial striate artery & $20 / 30(67)$ \\
Middle cerebral artery & $30 / 30(100)$ \\
Pericallosal artery & $30 / 30(100)$ \\
Posterior cerebral artery & $30 / 30(100)$ \\
Vertebral artery & $30 / 30(100)$ \\
Veins & \\
Basal vein & $5 / 30(17)$ \\
Great cerebral vein & $30 / 30(100)$ \\
Inferior sagittal sinus & $7 / 30(23)$ \\
Internal cerebral vein & $30 / 30(100)$ \\
Occipital sinus & $2 / 30(7)$ \\
Superior petrosal sinus & $4 / 30(13)$ \\
Straight sinus & $30 / 30(100)$ \\
Superior sagittal sinus & $23 / 30(77)$ \\
Thalamostriate vein & $14 / 30(47)$ \\
Transverse sinus & $26 / 30(87)$ \\
\hline
\end{tabular}

\section{1）水頭症}

軽症水頭症では，脳室の拡大に伴い軽度の血管の偏位 が認められたが，描出の程度には正常と特に差がなかっ た(Fig. 1,2).

重症水頭症では, 前大脳動脈, 傍脳梁動脈の上方への 著しい圧排所見が認められ, 症例によっては内大脳静脈, 直静脈洞の描出が悪かった(Fig.3).

\section{2 ) hydranencephaly}

hydranencephalyでは，内頸動脈は描出されたが，左中 大脳動脈と前大脳動脈の描出はできなかった(Fig.4). 本 症例では，右側頭葉は多少残っており，右中大脳動脈の 一部は描出された。

\section{3 ) Dandy-Walker syndrome}

Dandy-Walker syndrome (variant)では，後頭蓋窩囊胞， 水頭症が認められ, 囊胞の後部に直静脈洞が認められた (Fig.5).

\section{4 ) holoprosencephaly}

alober typeの症例では，通常の位置に前大脳動脈が描 出されず，正常血管像を得られなかった(Fig.6).

\section{5 ) 脳梁欠損症}

脳梁欠損症においては，正中矢状断で脳梁が認められ ず，屈曲した走行で前大脳動脈の分枝が認められた (Fig. 7A). また, 冠状断で脳梁動脈, 内大脳静脈が左右に開い て認められた(Fig.7B)。 


\section{6) くも膜真胞}

くも膜囊胞によって圧迫された脳梁周囲動脈の分枝や 周囲の静脈が描出された(Fig.8A,B). また本症例では, 脳梁欠損症を伴っており脳梁動脈の走行異常も認められ た (Fig.8C,D).

7 ) cavum velum interpositum

内大脳静脈が囊胞により左右または下方に偏位して認 められた(Fig.9).

\section{4. 考案}

新生児・未熟児において, 超音波断層法により脳内の構 造や疾患, 病態についての検討が, 容易に安全に行なわ れるようになってきた ${ }^{1)-3)}$. そして連続波ドプラやパル スドブラ法により脳血流速に関する多くの情報が得ら $れ^{144) 5}$ ，新生児頭部病変の検討において超音波検查は無 くてはならないものとなっている，しかしながら，従来 の超音波断層法では，頭蓋内血管は画面上で拍動として とらえられるのみであった ${ }^{3)}$.われわれが用いたカラー ドプラ断層法は, 本邦で開発され心蔵領域での応用が最 初であり ${ }^{6)}$, 血流を探触子に向かうものは赤系統色に, 遠 ざかるものは青系統色でリアルタイムに見ることを可能 とした。そしてその進歩はめざましいものがあり，頭蓋

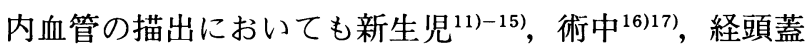
骨的に成人 ${ }^{18)}$ に応用が拡がりつつある. 特に新生児・未熟 児では頭蓋骨が薄く，さらに大泉門をエコーウィンドウ とすることができるため，成人に比較して容易に高画質 な像を得ることができる．また，新生児では動脈血流速 が比較的遅く aliasingが起こりにくいため, 画像が見やす いという利点もある，疾患としても，新生児期には脳出 血, 脳奇形などの中枢神経系病変も多く, カラードプラ 断層法により血管を描出できることの意義は大きいと考 えられる。

従来のカラードプラ断層装置による血流速検出最小值

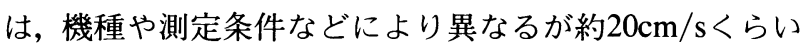
とされていた ${ }^{10)}$. このため, $20 \mathrm{~cm} / \mathrm{s}$ 以下の遅い血流であ る静脈系の表示はできず，表示できる血管は太い動脈の 一部であり，その応用範囲は脳血流速測定時に動脈の位 置の確認程度であった。しかしながら，装置の進歩によ り，われわれの使用したSSA-270Aでは，繰り返し周波数 を下げ，探触子を多探触子としSN比を向上させ，高画質 化, そして低速度の血流すなわ $10 \mathrm{~cm} / \mathrm{s}$ 以下の静脈血流 のカラー表示を可能にした ${ }^{12}$. 得られる画像は極めて高 画質であり, 動脈のみならず静脈血流もカラー画像とし て描出でき13)，またリアルタイムにダイナミックな動き
として血流をとらえることができる.

正常児における脳血管の描出率は, Table 2 に示すご とく血管によって差異がみられる，それは，(1)血管の太 さ, 血管の部位, 血管の走行, (2)血流速, (3)どこをエコー ウィンドウとするか, (4)エコーウィンドウとする大泉門 の大きさなどの違いによる. Table 2で示した描出率は, われわれがカラードプラの応用を始めた頃に施行した症 例も含んで打り，現在ではここに示すような動脈はほぼ $100 \%$ 描出でき, 静脈でもその描出率は著しく向上してい る。これは装置の細かな点に打ける改善や術者の技術の 向上, 測定時のflow filterや繰り返し周波数などの装置の 条件設定がより適切になってきたことが上げられる。今 後さらに描出が良くなることが考えられ，診断価值も増 すと思われる。

今回われわれは脳奇形における血管について検討した が，脳室や囊胞により偏位する血管が認められた。これ はシャント手術などの脳外科的処置が必要なときに, 脳 血管走行異常のスクリーニングとして役立つと思われた。 また, 脳梁欠損症では脳梁が無いために, 正常血管走行 と異なる屈曲した血管が認められた．脳梁欠損症は超音 波断層法で診断可能とされるが，必ずしも容易ではなく， 脳梁動脈の走行が不規則であることの確認は, 脳梁欠損 症の診断の助けになると考えられる。また，脳動静脈奇 形1116)17)，ガレン静脈瘤などの脳血管奇形や脳出血後の 脳血流障害などに関する検討にも有用であると思われる.

最近はドプラ法による脳血流速測定が盛んに行なわれ ているが，ドプラの入射角が正確でないと測定した血流 速の誤差は大きくなってしまうという問題点がある. 特 に脳奇形があると血管の偏位が大きく，カラードプラ断 層なしには正確な血流速を求めることは困難と考えられ る.さらに静脈血流速の検討 $\left.{ }^{12}\right)$ やECMO(extracorporeal membrane oxygenation)の時の脳の血行動態の検討 ${ }^{14)}$ も カラードプラ断層法を用いて行なわれており，これらの 検討には，その走行を知るためにもカラードプラ断層法 は必要なものと考えられる。

新生児・未熟児における脳血管に関する情報は, 脳血管 撮影はもとよりCT, MRIなども必ずしも非侵襲的とは 言えない. カラードプラ断層法による新生児脳血管像へ の臨床応用には, 映像視野などの問題はあるが, 脳血管 をリアルタイムに，安全に，容易に繰り返し見られるこ となど, 他検查にはない利点も多く, 従来難しかった脳 血管系の検查法の 1 つとして応用できると考えられた。 


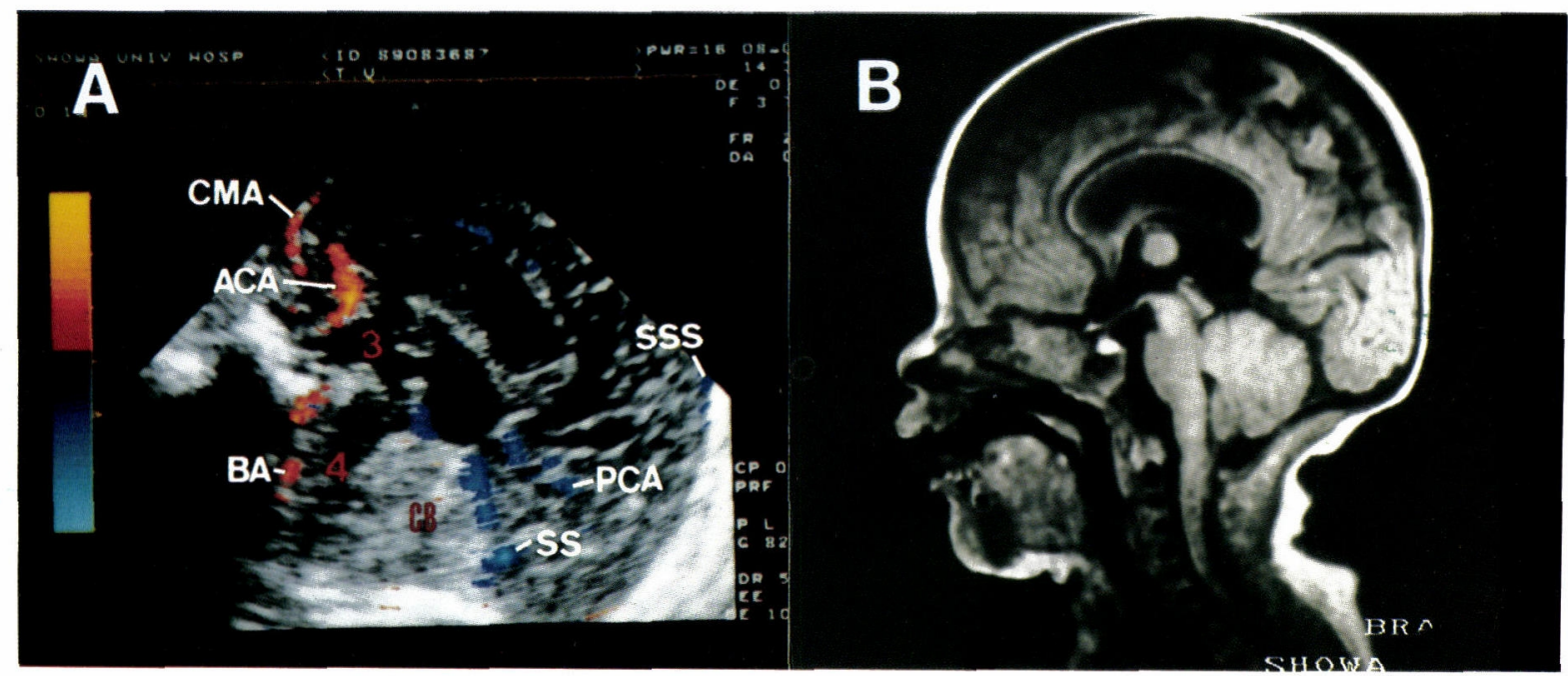

Fig. 1 Mild hydrocephalus. (A) and (B), 10-day-old boy. (A) Midsagittal US scan through the anterior fontanelle and (B) sagittal T1-weighted image (300/14) show moderate dilatation of lateral and third ventricles.

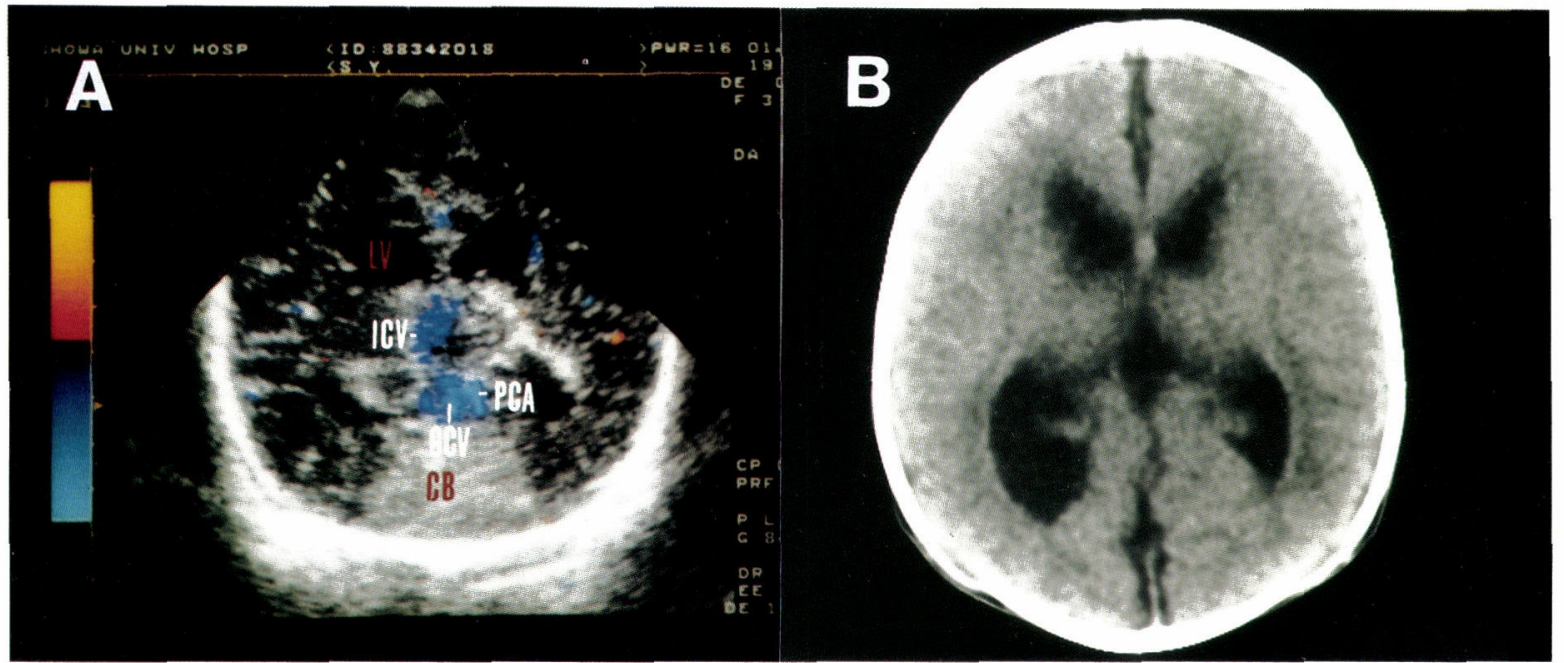

Fig. 2 Mild hydrocephalus. (A) and (B), 14-day-old boy. (A) Coronal US scan through the anterior fontanelle and (B) axial CT scan show moderate dilatation of lateral and third ventricles.

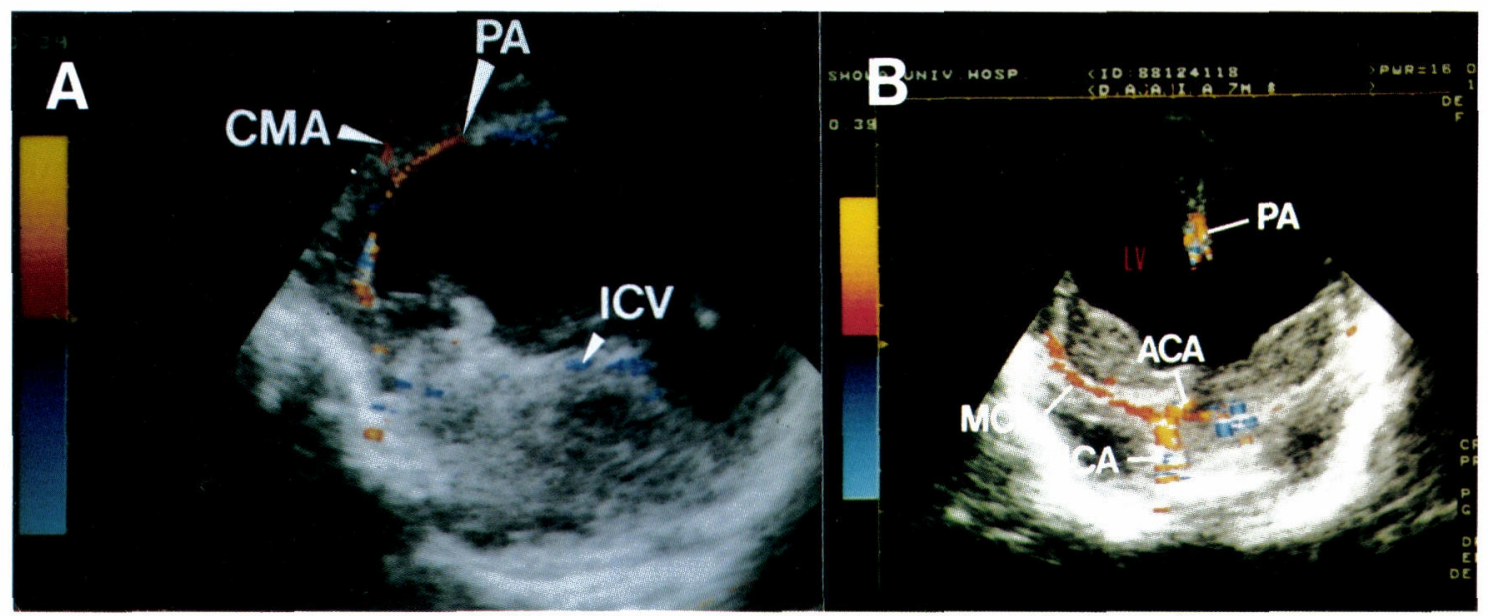

Fig. 3 Severe hydrocephalus. (A) and (B), 1-month-old boy. (A) Midsagittal US scan through the anterior fontanelle demonstrates a streched and elevated sweep of the anterior cerebral artery. (B) Coronal scan through the anterior fontanelle shows marked displacement of the middle cerebral artery laterally. 


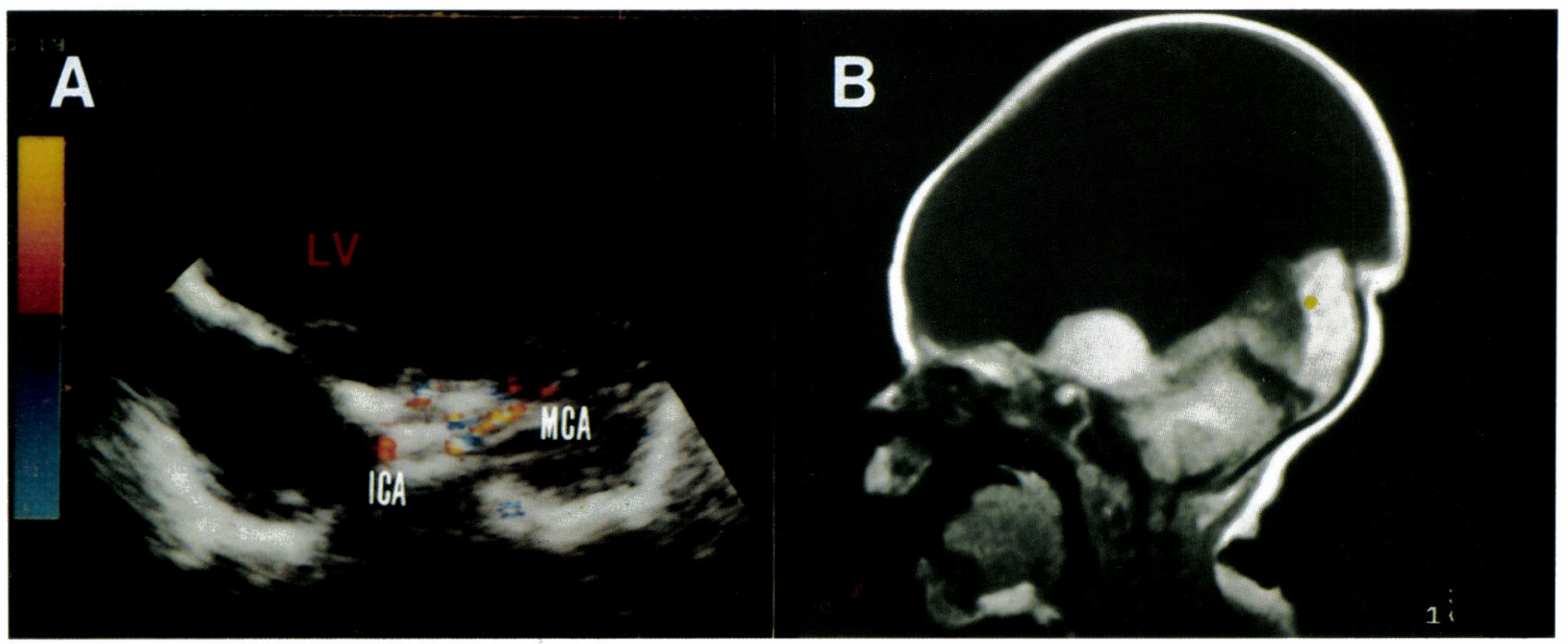

Fig. 4 Hydranencephaly. (A) and (B), 1-month-old girl. (A) Coronal US scan through the anterior fontanelle and (B) sagittal T1-weighted image (300/14) show thalamus and cerebellum in mid lower portion of head.

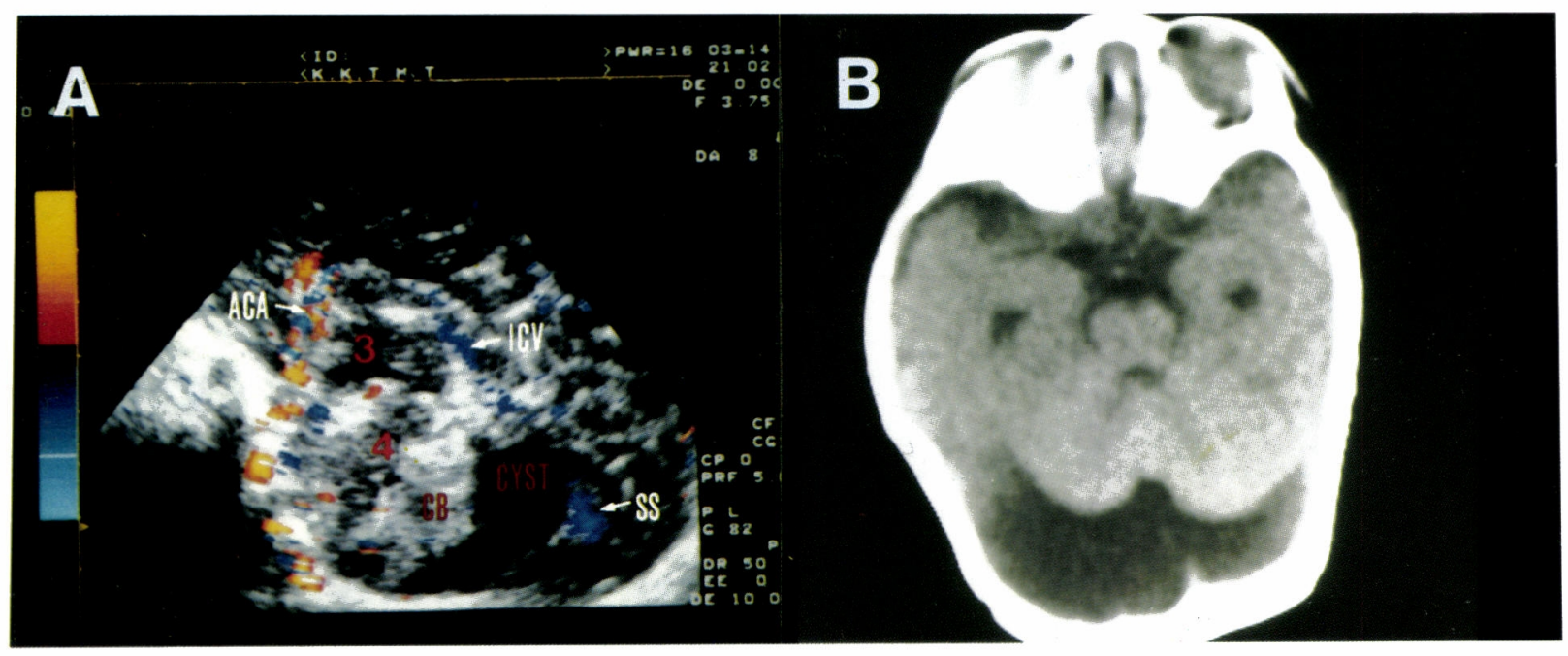

Fig. 5 Dandy-Walker variant. (A) and (B), 1-month-old girl. (A) Midsagittal US scan through the anterior fontanelle and (B) axial CT scan show large cyst in posterior fossa.

Figs legends

\begin{tabular}{llll}
\hline ACA & : Anterior cerebral artery & MCA & : Middle cerebral artery \\
BA & : Basilar artery & PA & : Pericallosal artery \\
CB & : Cerebellum & PCA & : Posterior cerebral artery \\
CMA & : Callosomarginal artery & SS & : Straight sinus \\
GCV & : Great cerebral vein & SSS & : Superior sagittal sinus \\
ICA & : Internal carotid artery & TH & : Thalamus \\
ICV & $\vdots$ Internal cerebral vein & 3 & \\
LSA & : Lateral striate artery & 4 & Third ventricle \\
LV & Lateral ventricle & & \\
\hline
\end{tabular}



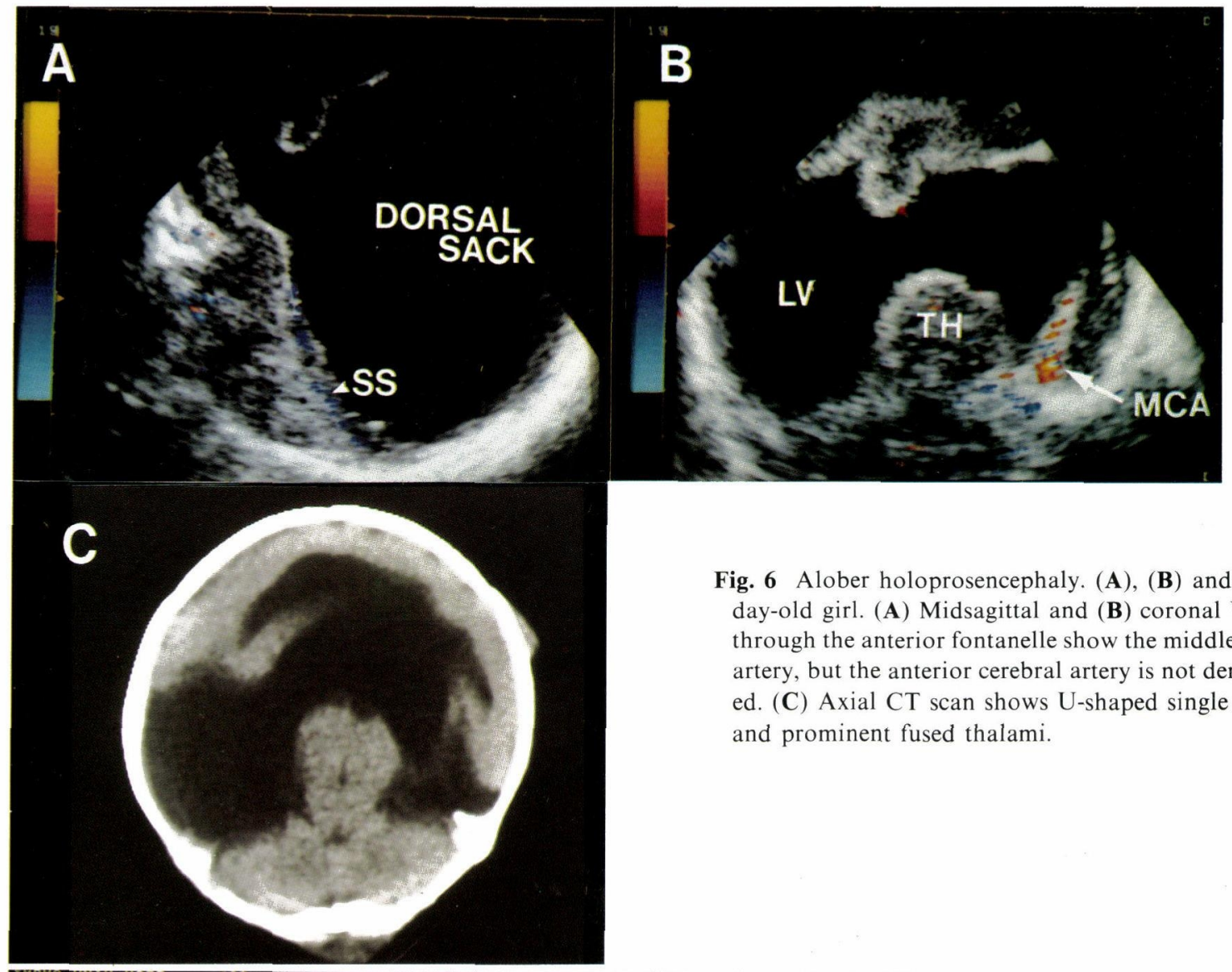

Fig. 6 Alober holoprosencephaly. (A), (B) and (C), 10day-old girl. (A) Midsagittal and (B) coronal US scans through the anterior fontanelle show the middle cerebral artery, but the anterior cerebral artery is not demonstrated. (C) Axial CT scan shows U-shaped single ventricle and prominent fused thalami.
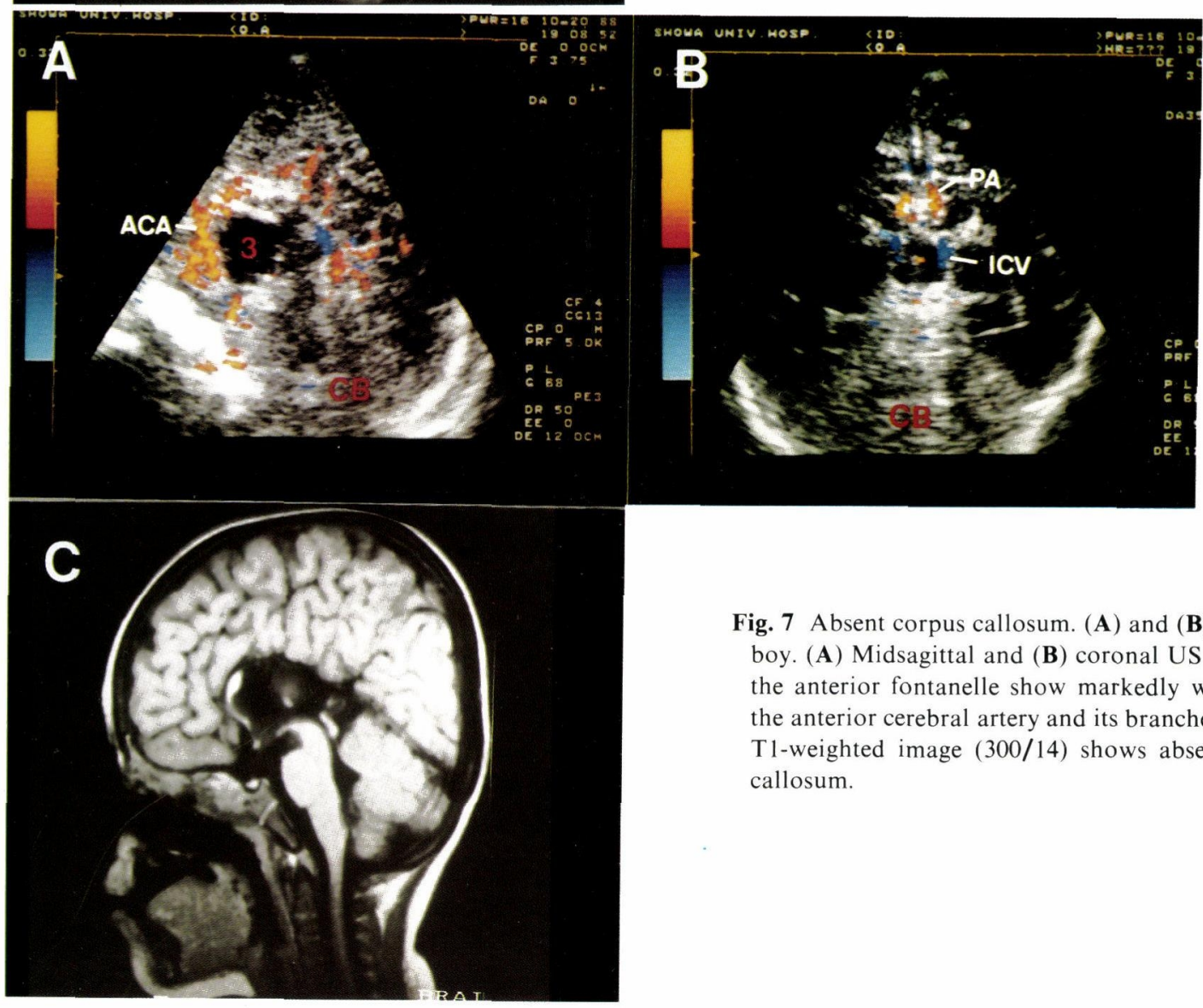

Fig. 7 Absent corpus callosum. (A) and (B), 7-month-old boy. (A) Midsagittal and (B) coronal US scans through the anterior fontanelle show markedly wavy course of the anterior cerebral artery and its branches. (C) Sagittal T1-weighted image (300/14) shows absence of corpus callosum. 


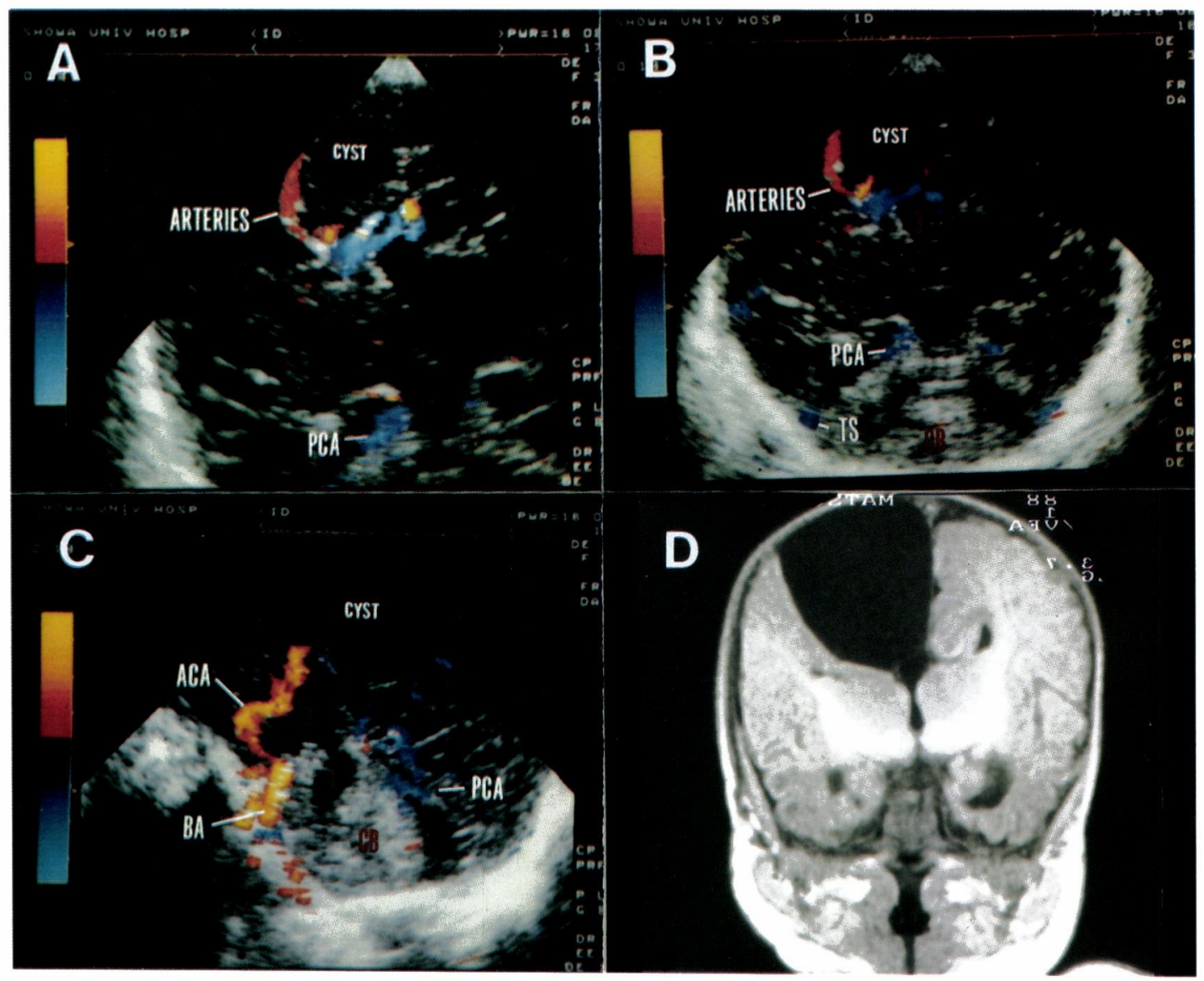

Fig. 8 Arachnoid cyst. (A), (B), (C) and (D), 4-day-old boy. (A),(B) Coronal US scans through the anterior fontanelle show displacement of the branches of the pericallosal artery. (C) Midsagittal US scan through the anterior fontanelle and (D) Coronal T1-weighted image(300/14) demonstrates arachnoid cyst, further absent corpus callosum shown.

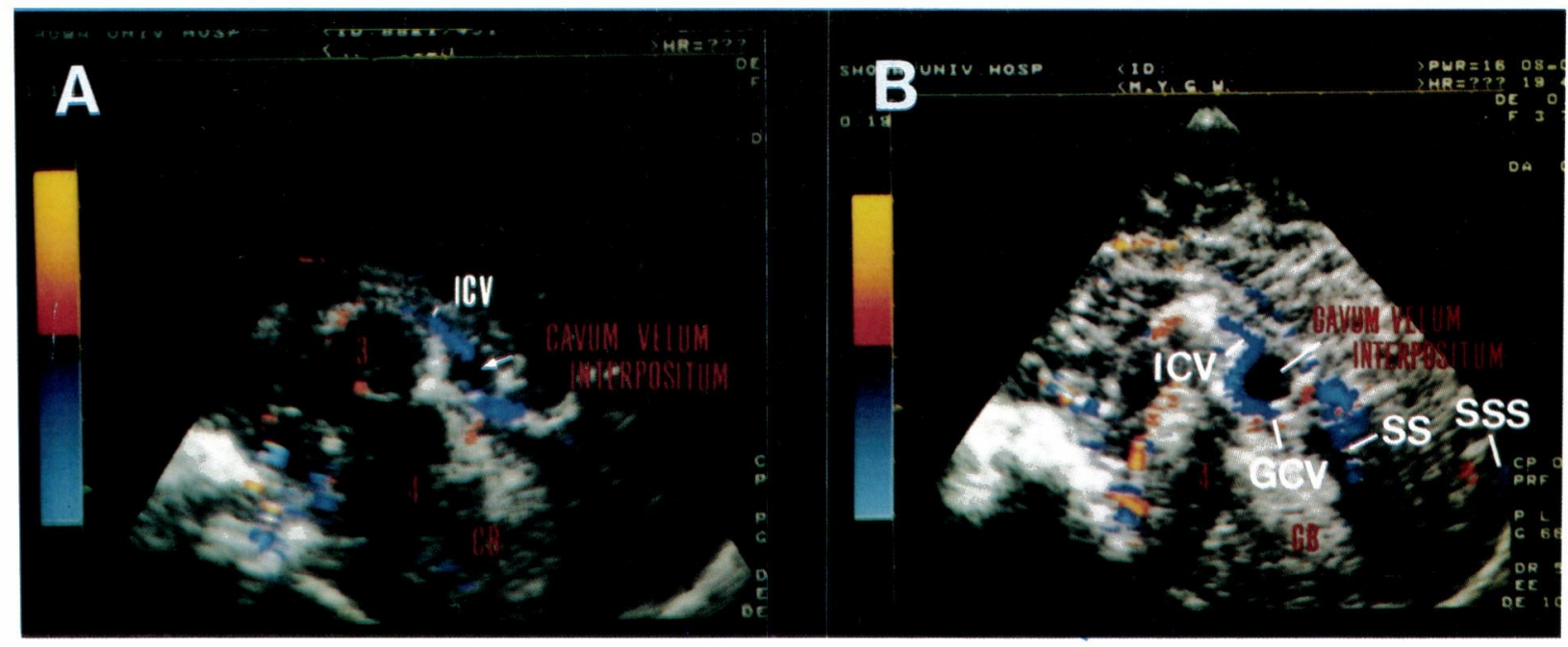

Fig. 9 Cavum velum interpositum. (A), 2-month-old girl. (B), 1-month-old boy. (A),(B) Midsagittal US scan through the anterior fontanelle show displacement of the internal cerebral vein. 


\section{5. おわりに}

新生児·乳児期の頭部領域においてカラードプラ断層 法は，今後様々な方向からの検討によりその意義は増す と思われ, さらに装置の進歩により新生児·乳児脳血管病 変の有力な検索法となると考えられる.

\section{文 献}

1) Volpe JJ. Neurology of the newborn. 2nd ed. Philadelphia : WB Saunders, 1987:311-61.

2) Babcock DS, Han BK. Cranial ultrasonography of infants. Baltimore: Williams \& Wilkins, 1981:246.

3) Levene MI, Williams JL, Fawer CL. Ultrasound of the infant brain. Clinics in Developmental Medicine. No.92, London: Blackwell Scientific Publications, 1985:148.

4) Levene MI. Neonatal neurology. Edinburgh: Churchill Livingstone, 1987:28-35.

5) Bode H. Pediatric applications of transcranial Doppler sonography. Wien: Springer-Verlag, 1988:144.

6) Namekawa K, Kasai C, Tsukamoto M, Koyano A. Imaging of blood flow using autocorrelation. Ultrasound Med Biol 1982; 8(suppl):138.

7) 尾本良三. カラーアトラス・リアルタイムドップラー断層心エ コ一図法(ドップラー断層の臨床). 改訂第 2 版. 東京：診断と治 療社, 1987:206

8) 尾本良三, 横平祐二, 高本真一, 許 俊鋭, 朝野晴彦, 滑川孝六, 近 藤祐司, 河西千広, 塚本成陪, 小谷野明. リアルタイム心腔内ドッ
プラ血流映像法(ドップラ断層)；その開発と心藏外科領域にお ける忘用. 外科診療 1983;25:1005-13.

9) Omoto R, Yokoe Y, Tsukamoto M. The development of real-time two-dimensional Doppler echocardiography and its clinical significance in acquired valvular diseases with special references to the evaluation of valvular regurgitation. Jpn Heart J 1984;25:325-40.

10) 尾本良三, 許 俊鋭. ドップラー心エコー図の原理と小児への応 用；ドップラー断層心エコー図 小児科Mook増刊 1 小児の 超音波診断·東京：金原出版。1986,64-87.

11) Merritt CRB. Doppler color flow imaging. JCU 1987;15:591-7.

12）田角 勝, 奥山和男, 川内章裕. 新生児の頭蓋内静脈血流速度。 脳と発達 1988;20:512-4.

13) Tatsuno $M$, Kubota $T$, Okuyama $K$, Kawauchi $A$. Intracranial vessels with color Doppler echoencephalography in infants. Brain Dev 1989;11:125-30.

14) Wong WS, Tsuruda JS, Liberman RL, Chirino A, Vogt JF, Gangitano E. Color Doppler imaging of intracranial vessels in the neonate. AJNR 1989;10:425-30.

15) Deeg $\mathrm{KH}$. Colour flow imaging of the great intracranial arteries in infants. Neuroradiology 1989;31:40-3.

16) Black KL, Rubin JM, Chandler WF, McGillicuddy JE. Intraoperative color-flow Doppler imaging of AVM's and aneurysms. J Neurosurg 1988;68:635-9.

17) Rubin JM, Hatfield MK, Chandler WF, Black KL, DiPietro MA. Intracerebral arteriovenous malformations ; intraoperative color Doppler flow imaging. Radiology 1989; 170:219-22.

18）古幡 博. 経頭蓋骨超音波断層法の新展開. Neurosonology 1989;2:8-15 